\section{Analysis of the Criteria for Selecting Heating Systems for Residential Buildings in Cold Climate}

\section{Jurgita Cerneckiene, Rokas Valancius*, Laura Stasiuliene}

Kaunas University of Technology, Faculty of Civil Engineering and Architecture Studentu st. 48, LT-51367 Kaunas, Lithuania

\section{Eugenijus Perednis}

Lithuanian Energy Institute, Laboratory for Renewable Energy and Energy Efficiency Breslaujos str. 3, LT-44403 Kaunas, Lithuania

\section{Juozas Vaiciunas}

Kaunas University of Technology, Faculty of Civil Engineering and Architecture Studentu st. 48, LT-51367 Kaunas, Lithuania

${ }^{*}$ Corresponding author: rokas.valancius@ktu.lt

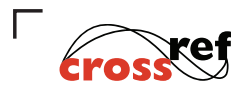

http://dx.doi.org/10.5755/j01.sace.23.2.21359

How to choose a heating system for a residential building? That is an important question for builders and owners of the buildings in Lithuania. Approximately the heating season in Lithuania starts by October $15^{\text {th }}$ and ends on April 15th. During this period, the average outdoor air temperature is about $0^{\circ} \mathrm{C}$. Many of the new single-family buildings in Lithuania are sold not completed as the new owners want to be free in choosing interior materials and engineering equipment. For this reason, many engineering decisions must be taken by the owner of the building, who is usually not a professional in the field of engineering. When choosing a heat source, it is always necessary to distinguish between many "for" and "against" arguments. Every heating option has both advantages and disadvantages. There is also a striking balance: the same heating method can never be either very comfortable and at the same time very cheap. When making a final decision, it is always recommended to compare the ratio of heat to the price and comfort, of course, taking into account energy and fuel price forecasts.

The article provides information that helps the building owner to navigate in the field of different engineering solutions that affect the future maintenance costs, efficiency, environmental aspects and comfort level of the building.

Keywords: residential building, heating system, energy prices.

The building sector accounts for $40 \%$ of the final energy consumption and $36 \%$ of $\mathrm{CO}_{2}$ emissions in Lithuania and EU countries (European Commission 2018). Space heating and hot water accounts for about $26 \%$ of all final energy consumption in the EU (Bosh et al. 2008). European Commission has set the new target of reducing the $\mathrm{CO}_{2}$ emissions by $90 \%$ for the building sector by the year 2050 (European Commission 2011). As reported in the $2014 / 15$ European work program, more than $17 \%$ of the primary energy savings potential of the EU for 2050 (European Commission 2015) to the building retrofit is related.

The largest part of buildings in Lithuania was built in the second part of $20^{\text {th }}$ century. About $60 \%$ of Lithuanian population resides in multi-family buildings constructed during 1961-1990. About 40\% of people in Lithuania lives in one or two-family buildings (EHPA 2017).
JSACE $2 / 23$

Analysis of the Criteria for Selecting Heating Systems for Residential Buildings in Cold Climate

Received 2018/08/08

Accepted after revision 2018/09/26

\section{Introduction}

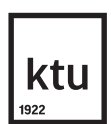

Journal of Sustainable Architecture and Civil Engineering Vol. 2 / No. 23 / 2018 pp. $69-78$ DOI 10.5755/j01.sace.23.2.21359 
Approximately heating season in Lithuania starts by October $15^{\text {th }}$ and ends on April $15^{\text {th }}$. According Lithuanian legislation for thermal energy supply and consumption heating season can be started when the average outdoor air temperature is below $+10^{\circ} \mathrm{C}$ for three consecutive days, and complete when the temperature is three consecutive times higher than $+10^{\circ} \mathrm{C}$ (Rules for supply and consumption of thermal energy). During this period, the average outdoor air temperature is about $0^{\circ} \mathrm{C}$. According to the regulations comfort temperature in living rooms and offices during a heating season should be in the range of 18 to $22^{\circ} \mathrm{C}$. Average energy consumption for space heating is $101 \mathrm{kWh} /$ $\mathrm{m}^{2}$, domestic hot water heating takes $11.2 \mathrm{kWh} / \mathrm{m}^{2}$ and $75.1 \mathrm{kWh} / \mathrm{m}^{2}$ is used for other's needs (EHPA 2017). Compared to the other EU countries with similar climate conditions, energy consumption for residential heating is approximately 1.8 times higher in Lithuania (Streimikiene 2014).

The survey (ESO 2017) performed in 2016 showed that in the major Lithuanian cities two-thirds of the population use centralized district heating $(C D H)$, the remaining - gas heating $(18 \%)$ or solid fuel - firewood or charcoal (15\%). Other heat sources, such as electricity, geothermal heating or pellet boilers, are used by a very small proportion of the population. According to the results of the survey, the choice of the heating method is influenced by the price and convenience. The priority for these heating criteria was provided by $42 \%$ and $39 \%$ of respondents during the survey, respectively. The comfort was especially emphasized by those residents whose home was heated by natural gas (44\%), but the price was also a very important factor for them (38\%).

When choosing a heating source, it is always necessary to distinguish between many arguments. Clearly, every heating option has both advantages and disadvantages. This article aims to provide information that helps the building owner to navigate in the field of different engineering solutions that affect the future maintenance costs, efficiency, environmental aspects and comfort level in the building.

Climate conditions of Lithuania

Lithuania has typical European continental climate with warm, dry summers and fairly severe winters. January is the coldest month with daytime temperatures usually around $-5^{\circ} \mathrm{C}$. However, periods with temperatures of about $-20^{\circ} \mathrm{C}$ or above $0{ }^{\circ} \mathrm{C}$ can last for few days or weeks. Furthermore, heavy snowfall or even snowstorms are also possible. The weather is often windy, cold and humid due to proximity to Baltic Sea. Temperature in summer can reach $20-25^{\circ} \mathrm{C}$. July is the warmest month with an average temperature of $18^{\circ} \mathrm{C}$. Temperature peaks above $30^{\circ} \mathrm{C}$ can occur and last for few weeks. Rain with heavy thunderstorms is common occurrence. On another hand, climate change cannot be ignored; winters are getting warmer with only a few days or weeks with snowfall.

According to Lithuanian regulations it is still recommended to use a climatic data from 1961 to 1990 (RSN 156-94) although official data from later period (average temperature of period 19812010) also exists (Galvonaite A. et al). The average temperatures in Kaunas city are presented in Table 1. These temperatures are near the average values of Lithuania with $0.7 \div 0.8$ deviation from Lithuanian average values. (Galvonaitè A. et al)

\begin{tabular}{|c|c|c|c|c|c|c|c|c|c|c|c|c|}
\hline \multirow{2}{*}{$\begin{array}{c}\text { Temperature, } \\
{ }^{\circ} \mathrm{C}\end{array}$} & \multicolumn{12}{|c|}{ Month } \\
\hline & 1 & 2 & 3 & 4 & 5 & 6 & 7 & 8 & 9 & 10 & 11 & 12 \\
\hline Avg. (7.25) & -3.25 & -3.25 & 0.75 & 7.25 & 12.75 & 15.75 & 18.25 & 17.75 & 12.75 & 7.75 & 1.75 & -2.25 \\
\hline Highest & 9.3 & 14.8 & 20.2 & 27.9 & 31.4 & 32.8 & 34.9 & 34.7 & 29.7 & 23.9 & 16.7 & 11.1 \\
\hline Lowest & -35.8 & -36.3 & -26.3 & -12.0 & -4.9 & -0.2 & 4.4 & 0.3 & -3.2 & -13.7 & -22.5 & -28.5 \\
\hline
\end{tabular}

Average (19812010), highest and lowest (19001990) monthly temperature in Kaunas city

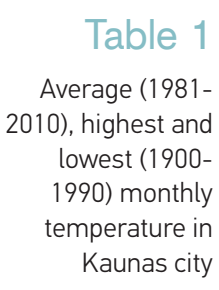


Lithuanian energy market is quite unique in the European context; district heating occupies more than $55 \%$ of the total thermal market (LSTA 2011). Quite frequently, natural gas $11.9 \%$, biofuel $25 \%$, coal $5.2 \%$ or in some cases electricity $0.22 \%$ is used for building heating systems (EHPA 2017).

The average price of district heating in Lithuanian cities is $0.05 € / \mathrm{kWh}$ (Table 2). In recent years, district heating energy price dropped by $8 \%$ (LSTA 2018). Switching from natural gas to biofuel reduced the district heating energy price significantly in the last five years. Due to a dramatic decline in oil and natural gas prices, conventional fuel prices also decreased by 35\% in the last five years. Global events show that in the near future, the price of energy tends to increase.

In 2017 natural gas prices in Lithuania for citizens varied from 0.38 to $0.64 € / \mathrm{m}^{3}$, depending on the consumption per year. Electricity prices varied from 0.077 to $0.124 € / \mathrm{kWh}$, depending on a selected tariff (Regula 2018).

The international situation in the price of biofuels (firewood) does not have an important direct impact, but the price of petroleum products has, as these are needed for the production of biofuels and transportation. Therefore, it is also expected that prices will increase in the field of biofuel.

Despite the minor fluctuation in recent years, it is noticeable that traditional energy (biofuel, natural gas, electricity, centralized district heating) prices are increasing slowly.

\begin{tabular}{c|c|c|c|c|c}
\hline \multirow{2}{*}{ Year } & \multicolumn{5}{|c}{ Eur/MWh } \\
\cline { 2 - 6 } & CDH ${ }^{1)}$ & Natural gas ${ }^{2)}$ & Electricity $^{3)}$ & Firewood $^{4)}$ & Wood pellets $^{5)}$ \\
\hline 2015 & 62.6 & 45.2 & 127.0 & 31.6 & 37.8 \\
\hline 2016 & 57.1 & 41.9 & 113.0 & 35.5 & 33.0 \\
\hline 2017 & 50.1 & 40.3 & 113.0 & 37.3 & 36.5 \\
\hline
\end{tabular}

1) average CDH energy price for residents (LSTA 2018);

2) the price of energy from natural gas for residents using from $500 \mathrm{~m}^{3}$ to $20000 \mathrm{~m}^{3}$ of gas per year (Regula 2018);

3) one-time zone tariff, "Standard" source (Regula 2017);

4) the price of energy from chopped birch firewood with $20 \%$ humidity;

5) the price of energy from deciduous trees wood pellets.

There are different traditions of purchasing of residential buildings in different countries. It is popular to buy a residential building with unfinished construction works in Lithuania as the owner feels free to make most acceptable interior and building comfort solutions. One of the decisions that owners prefer to make according their lifestyle and employment is selecting the heat source. Apart from other criteria discussed in the paper, it is necessary to evaluate how the selected heat source influences the overall energy efficiency of a building. The energy efficiency of a building (energy performance class - EPC) is a state-regulated criterion, introduced as one of the means to implement the adopted cross-border agreements (Directive 2010/31/EU) and thus to manage climate change.

The energy performance class of buildings, that has the building permit issued after $1^{\text {st }}$ January 2016, should not be lower than A, after $1^{\text {st }}$ January 2018 - not lower than A+ and after $1^{\text {st }}$ January 2021 - energy performance class must reach A++ class (STR 2.01.02:2016).

During the energy performance assessment, the building is analyzed according to 7 criteria for classes A and A+ and 8 criteria for class A++. Heat source used in heating and domestic hot water systems has direct influence for two criteria used in $A$ and $A+$ evaluation and for 3 criteria in A++ evaluation.

In most cases, the selection of heat source for a building and the modeling of its energy performance class is already provided during the design stage. Therefore, it is important for the owner of

\section{Energy prices in Lithuania}

\section{Table 2}

Energy price dynamics in 20152017 (VAT incluted)

\section{The influence of the heating system and the heat source to the energy efficiency of the building}


the building to know if the heating alternative he wants to choose is not worse than the designed case. For example, for a residential building of $150 \mathrm{~m}^{2}$ with specific heat losses of $82.39 \mathrm{~W} / \mathrm{K}$, natural ventilation, and a heat pump used for heating (with thermal energy source - air) - energy performance class A+ would be qualified. If the owner would change the designed heat source into solid fuel or gas boiler, such building would be qualified as a B class building.

One of the quantitative indicators according to which the owner can compare different heating sources is the calculated efficiency of the building heating system $\mathrm{n}_{h s}$, which is calculated according to the formula (STR 2.01.02:2016)

$$
\eta_{h s}=\eta_{1} \cdot \eta_{2} \cdot k_{2 . r e g}
$$

where $n_{1}$ - coefficient of the heating system automatic regulation level (Table 3 ), $n_{2}$ - coefficient of the thermal efficiency of the heat source (Table 4), $k_{\text {2.reg }}$ - correction factor for evaluating the efficiency of a heat source when coefficient of the efficiency is declared by the producer of the heat source (Table 5).

Table 3

The coefficients of the heating system automatic regulation level $\mathrm{n}_{1}$

Table 4 The coefficients of the thermal efficiency of the heat source $n_{2}$
Table 5

Correction factors

$k_{2 \text {.reg }}$ for evaluating the efficiency of a heat source when the coefficient of the efficiency is declared by the producer of the heat source

\begin{tabular}{l|c}
\hline \multicolumn{1}{c|}{ Regulation equipment } & $\mathrm{n}_{1}$ \\
\hline $\begin{array}{l}\text { No regulation equipment } \\
\text { Regulation equipment controls the heating system in the whole building: only thermostatic } \\
\text { regulators for heat emitters or inside/outside thermostat are installed }\end{array}$ & 0.88 \\
\hline $\begin{array}{l}\text { Regulation equipment controls the heating system in the whole building: both thermostatic } \\
\text { regulators for heat emitters and inside/outside thermostat are installed }\end{array}$ & 0.98 \\
\hline \begin{tabular}{l} 
Regulation equipment controls the heating system in the part of the building \\
\hline
\end{tabular}
\end{tabular}

\begin{tabular}{l|c|l|c}
\multicolumn{1}{c|}{ Heat source } & $\mathrm{n}_{2}$ & \multicolumn{1}{c|}{ Heat source } & $\mathrm{n}_{2}$ \\
\hline Central heat networks, manual regulation & 0.90 & Electric heating, manual regulation & 0.90 \\
\hline $\begin{array}{l}\text { Central heat networks, automatic } \\
\text { regulation }\end{array}$ & 1.00 & Electric heating, automatic regulation & 1.00 \\
\hline Gas boiler, manual regulation & 0.80 & Heat pump, energy taken from the air & $\mathrm{n}_{\mathrm{SPF}}=3.00$ \\
\hline Gas boiler, automatic regulation & 0.94 & Heat pump, energy taken from the soil & $\mathrm{n}_{\mathrm{SPF}}=4.00$ \\
\hline Radiant gas heater & 1.00 & Heat pump, energy taken from the water & $\mathrm{n}_{\mathrm{SPF}}=4.50$ \\
\hline Liquid fuel boiler, manual regulation & 0.75 & Furnaces & 0.50 \\
\hline Liquid fuel boiler, automatic regulation & 0.87 & Open fireplace & 0.20 \\
\hline Solid fuel boiler, manual regulation & 0.70 & $\begin{array}{l}\text { Fireplaces with a capsule, when the } \\
\text { combustion process uses warm indoor air }\end{array}$ & 0.30 \\
\hline Solid fuel boiler, automatic regulation & 0.85 & $\begin{array}{l}\text { Fireplaces with a capsule, when the } \\
\text { combustion process uses outdoor air }\end{array}$ & 0.50 \\
\hline
\end{tabular}

\begin{tabular}{l|l}
\hline \multicolumn{1}{c|}{ Heat source } & $\mathrm{k}_{2 \text { re }}$ \\
\hline Gas boiler & 0.85 \\
\hline Liquid fuel boiler & 0.86 \\
\hline Solid fuel boiler & 0.82 \\
\hline Electric heating & 0.90 \\
\hline Other cases & 1.00 \\
\hline
\end{tabular}


If the efficiency of the selected heating system alternative of the building $n_{h s}$ is not lower than the one according which the energy performance class of the building has been modeled, the user can make a decision without additional calculations, otherwise it is necessary to make additional calculation and check if the requirements of the legislation are met. Due to unfavorable results of calculations, i.e., when the required energy performance class cannot be achieved, it may be necessary to increase the insulation layers of the building partitions or maintain a design heat source.

The other criteria according to which decision of heating source selection can be made are more related to habits and individual situation of a resident. One of these criteria is space for equipment, which is essential for modern homes. It is important to emphasize that the peculiarities of daily maintenance remain an urgent issue for building residents. Furthermore, environmental pollution has long been ignored; nowadays local environment pollution is one of the most important criteria. To have a more reliable heat source, an additional (alternative) heat generator is often considered. Therefore, the chosen heat source should be compatible with other alternatives.

In this case, the heat source is a boiler room, i.e., components, that can vary widely depending on the selected heating type. Meanwhile, the heating system includes pipelines with heating devices or without them (in underfloor and panel heating systems).

Detailed descriptions of different heating system alternatives are presented in Table 6 .

\begin{tabular}{|c|c|c|c|c|}
\hline \multirow[b]{2}{*}{ Heating source } & \multicolumn{4}{|c|}{ Criterion } \\
\hline & Space for equipment & $\begin{array}{l}\text { Smooth/fast } \\
\text { power control }\end{array}$ & $\begin{array}{c}\text { Daily } \\
\text { maintenance }\end{array}$ & $\begin{array}{l}\text { Local environment } \\
\text { pollution }\end{array}$ \\
\hline $\begin{array}{l}\text { Solid fuel (firewood) } \\
\text { boiler without } \\
\text { accumulation tank }\end{array}$ & $\begin{array}{l}\sim 6 \mathrm{~m}^{2} \\
+ \text { space for firewood storage } \\
\text { (required area depends on } \\
\text { the amount of firewood that } \\
\text { is needed to accumulate) }\end{array}$ & $\begin{array}{l}\text { uneven } \\
\text { power } \\
\text { regulation }\end{array}$ & \multirow{2}{*}{$\begin{array}{l}\text { bringing } \\
\text { firewood to } \\
\text { the boiler } \\
\text { room, } \\
\text { removing } \\
\text { ashes }\end{array}$} & \multirow{3}{*}{$\begin{array}{l}\text { a significant amount } \\
\text { of particulate } \\
\text { matter, carbon } \\
\text { dioxide, nitrogen } \\
\text { oxides are released } \\
\text { into the local } \\
\text { environment }\end{array}$} \\
\hline $\begin{array}{l}\text { Solid fuel (firewood) } \\
\text { boiler with } \\
\text { accumulation tank }\end{array}$ & $\begin{array}{l}\sim 8 \mathrm{~m}^{2} \\
+ \text { space for firewood storage } \\
\text { (required area depends on } \\
\text { the amount of firewood that } \\
\text { is needed to accumulate) }\end{array}$ & $\begin{array}{l}\text { accumulation } \\
\text { tank ensures } \\
\text { smooth } \\
\text { power control }\end{array}$ & & \\
\hline Wood pellet boiler & $\begin{array}{l}\sim 8 \mathrm{~m}^{2} \\
+ \text { space for wood pellet } \\
\text { storage (required area } \\
\text { depends on the amount of } \\
\text { wood pellets that is needed } \\
\text { to accumulate) }\end{array}$ & $\begin{array}{l}\text { wide power } \\
\text { regulation }\end{array}$ & $\begin{array}{l}\text { filling wood } \\
\text { pellet tank, } \\
\text { removing } \\
\text { ashes }\end{array}$ & \\
\hline $\begin{array}{l}\text { Natural gas boiler } \\
\text { (condensing } \\
\text { boiler with heat } \\
\text { exchanger for } \\
\text { domestic hot water) }\end{array}$ & up to $2 m^{2}$ & \multirow{4}{*}{$\begin{array}{l}\text { wide and } \\
\text { smooth } \\
\text { power } \\
\text { regulation }\end{array}$} & \multirow{4}{*}{ no need } & $\begin{array}{l}\text { an insignificant } \\
\text { amount of } \\
\text { particulate matter, } \\
\text { carbon dioxide, } \\
\text { nitrogen oxides are } \\
\text { released into the } \\
\text { local environment }\end{array}$ \\
\hline $\begin{array}{l}\text { Heat pump, type } \\
\text { "air to water" }\end{array}$ & up to $4 \mathrm{~m}^{2}$ & & & \multirow{3}{*}{ no local pollution } \\
\hline $\begin{array}{l}\text { Heat pump, type } \\
\text { "soil to water" }\end{array}$ & up to $4 \mathrm{~m}^{2}$ & & & \\
\hline $\begin{array}{l}\text { Centralized district } \\
\text { heating }\end{array}$ & up to $2 \mathrm{~m}^{2}$ & & & \\
\hline
\end{tabular}

\section{Criteria for selecting heating systems for residential buildings}

\section{Table 6}

Description of heating system alternatives according to different criteria 
The solid fuel boiler room consists of a solid fuel boiler, a stack unit, a storage tank for heat storage, a domestic hot water tank, circulating pumps, regulating equipment, controller, and pipelines. In recent years, the level of automation of solid boilers has been improved, which has simplified boiler care and increased system efficiency (Cerneckiene et al. 2018).

The natural gas boiler room is the simplest. Gas boiler can be installed in the kitchen or bathroom. On the other hand, specific technical requirements for a room must be fulfilled before gas boiler installation. The height of the room must be at least $2.2 \mathrm{~m}$. The room must have a window of $0.05 \mathrm{~m}^{2}$ for each cubic meter of the room. If the volume of the room is $20.0 \mathrm{~m}^{3}$ or more, the window area must be at least $1.0 \mathrm{~m}^{2}$. In most cases the gas boiler with domestic hot water preparation function is mounted on the wall, and the pipelines from the heating system as well as gas supply pipe are connected to the boiler. This option of the gas boiler was evaluated in further calculations. Evaluating the alternative heat source - the heat pump, the underground collector (horizontal or vertical) in the yard must be included in the boiler room installation. Instead of underground collector outdoor air can be used as heat source. However, in cold climates efficiency of this type of heat pump is lower (Honkapuro and Koreneff 2017; Stuart et al. 2013). Other elements of the boiler room with the heat pump are the heat pump module with compressor and circulation pumps, the domestic hot water tank and other auxiliary boiler control equipment. An important factor is that heat pumps work effectively only with low-temperature heating systems, e.g., underfloor heating. The boiler room is very compact for those buildings that can connect to district heating network: it consists of the equipment for reducing the district water parameters (temperature, pressure, etc.), a heat exchanger for heating systems as well as for domestic hot water system, circulating pumps, thermal energy accounting devices.

There are other heating types such as direct electric heating, liquid gas boilers or liquid fuel boiler. However, due to the low popularity of such heating types in recent years, these heating types were not evaluated.

The economic benefit is often the most urgent issue when evaluating and choosing the source of heat generation. The economic benefit in this study was estimated by calculating the discounted price of thermal energy. It is an economic indicator that estimates cost over a period of 10 years. It was assumed that the temperature in the building is $+20^{\circ} \mathrm{C}$ and the annual heat demand for heating and hot water is $15,000 \mathrm{kWh}$. It was also assumed that the entire cost of the heating system is covered during the installation. The lifespan of the heating system was considered to be ten years. Parameters used for financial assessment of the heating systems are presented in Table 7.

Investments into the heat source vary widely and depend on the chosen equipment, manufacturer, the level of automation, cost of gas, cost of energy from district heating and the complexity of the installation work. Average investment into a heating source of $150 \mathrm{~m}^{2}$ A class single-family building in Lithuania with underfloor heating is presented in Table 8. Investments in the heat source

\begin{tabular}{|c|c|c|}
\hline & & \\
\hline Table 7 & The lifespan of the heating system, years & 10 \\
\hline Parameters used & Specific district heating energy price (average), Eur/kWh & 0.050 \\
\hline & Specific energy from natural gas price (average), Eur/kWh & 0.040 \\
\hline & Specific energy from solid fuel (average), Eur/kWh & 0.047 \\
\hline & Specific energy from wood pellets (average), Eur/kWh & 0.106 \\
\hline & Specific electricity costs (standard), Eur/kWh & 0.113 \\
\hline & Index for energy prices, $\%$ per year & 2.0 \\
\hline & Interest capital, \% & 2.5 \\
\hline & Running costs, \% & 1.5 \\
\hline
\end{tabular}




\begin{tabular}{l|c|c|c}
\hline \multicolumn{1}{c|}{ Heating source } & $\begin{array}{c}\text { Average primary } \\
\text { installation cost, Eur }\end{array}$ & $\begin{array}{c}\text { Fuel cost for the } \\
\text { 10-year period, Eur }\end{array}$ & $\begin{array}{c}\text { Total installation and } \\
\text { fuel cost for the } \\
\text { 10-year period, Eur }\end{array}$ \\
\hline $\begin{array}{l}\text { Solid fuel (firewood) boiler without } \\
\text { accumulation tank }\end{array}$ & 1800 & 6249 & 8566 \\
\hline $\begin{array}{l}\text { Solid fuel (firewood) boiler with } \\
\text { accumulation tank }\end{array}$ & 4300 & 5873 & 11441 \\
\hline \begin{tabular}{l} 
Wood pellets boiler \\
\hline $\begin{array}{l}\text { Condensing gas boiler with heat } \\
\text { exchanger for domestic hot water }\end{array}$
\end{tabular} & 2900 & 5809 & 11089 \\
\hline $\begin{array}{l}\text { Heat pump, type "air to water" } \\
\text { SPF*=3.5 }\end{array}$ & 6500 & 7490 & 10849 \\
\hline $\begin{array}{l}\text { Heat pump, type "soil to water" } \\
\text { SPF*=4.5 }\end{array}$ & 11800 & 5504 & 12349 \\
\hline Centralized district heating & 3200 & 4526 & 16750 \\
\hline
\end{tabular}

\section{* Seasonal Performance Factor}

were evaluated by comparing prices of at least three suppliers (gas and district heating) during the first quarter of 2018 in Kaunas city. It was assumed that distance (connection length) from the building to the gas or district heating network is up to $10 \mathrm{~m}$.

In Lithuania, some limited subsidy systems and funds for renewable energy installations exists since 2005. Depending on a project, it is possible to apply for a subsidy covering from 25 to $100 \%$ of initial costs. For example, it is possible to get a subsidy up to $30 \%$ for the single-family building (but only for buildings older than five years), up to $40 \%$ for multifamily buildings and up to $100 \%$ for hospitals. In this study subsidy for a heat source installation were not assessed.

The obtained data (Fig. 1) shows that heating systems with solid fuel or wood pellets boilers are the cheapest way to cover the heating and domestic hot water demand of the residential building, especially if it is possible to buy firewood cheaper than the average market price. The average

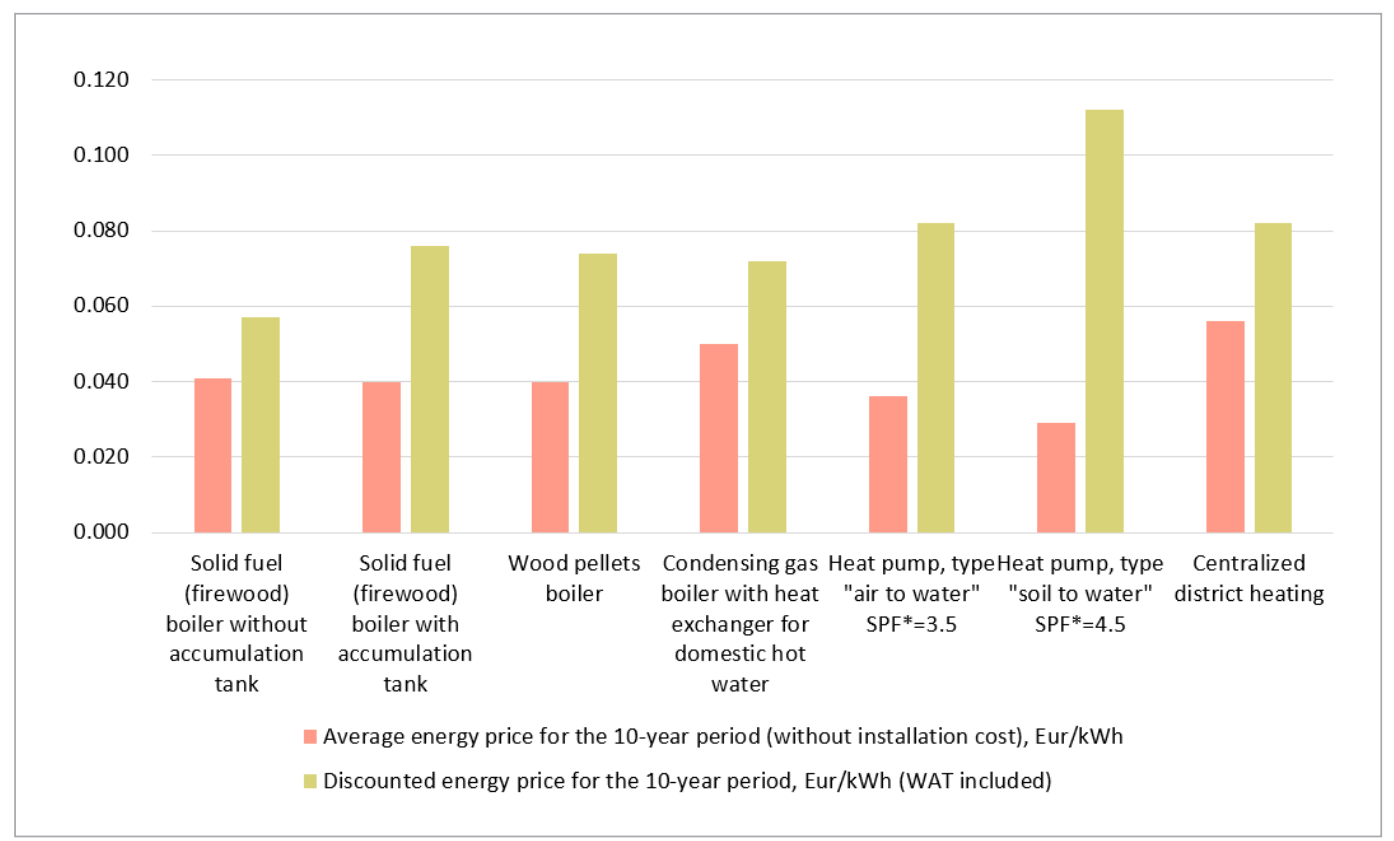

\section{Results}

Fig. 1

Energy prices for heating (VAT included) 
energy price of this system for the 10-year period (without installation cost) is 0.040 Eur $/ \mathrm{kWh}$. The most expensive heating system is a system with a heat pump (type "soil to water"). However, if investments in the installation of this type of heating system are not evaluated, this type of heat source would give an energy price of 0.029Eur $/ \mathrm{kWh}$.

Regarding the comfort level, the least comfortable heat source would be solid fuel boilers. Due to the daily maintenance of the boiler, i.e., it is necessary to bring firewood to the boiler room, clean the boiler or remove the ashes every day. It can be argued that gas boiler or centralized district heating as a heat source are the most attractive regarding comfort, investment, and energy costs for the 10-year period. However, natural gas or district heating networks are not available in all areas. Therefore, choosing a heat source for a building that cannot be connected to the natural gas or district heating networks and at the same time seeking to achieve comfort and ecological environment, a better choice would be to use "air to water" heat pump. The energy price of this system is higher and exceeds 0.036 Eur/kWh excluding installation. However, the investments in this system are lower by 50\% compared to "soil to water" heat pump system.

Recommendations for the selection of the heat source for a residential building in a cold climate country are presented in Fig. 2.

Fig. 2

Recommendations for the selection of the heat source for a residential building in a cold climate country

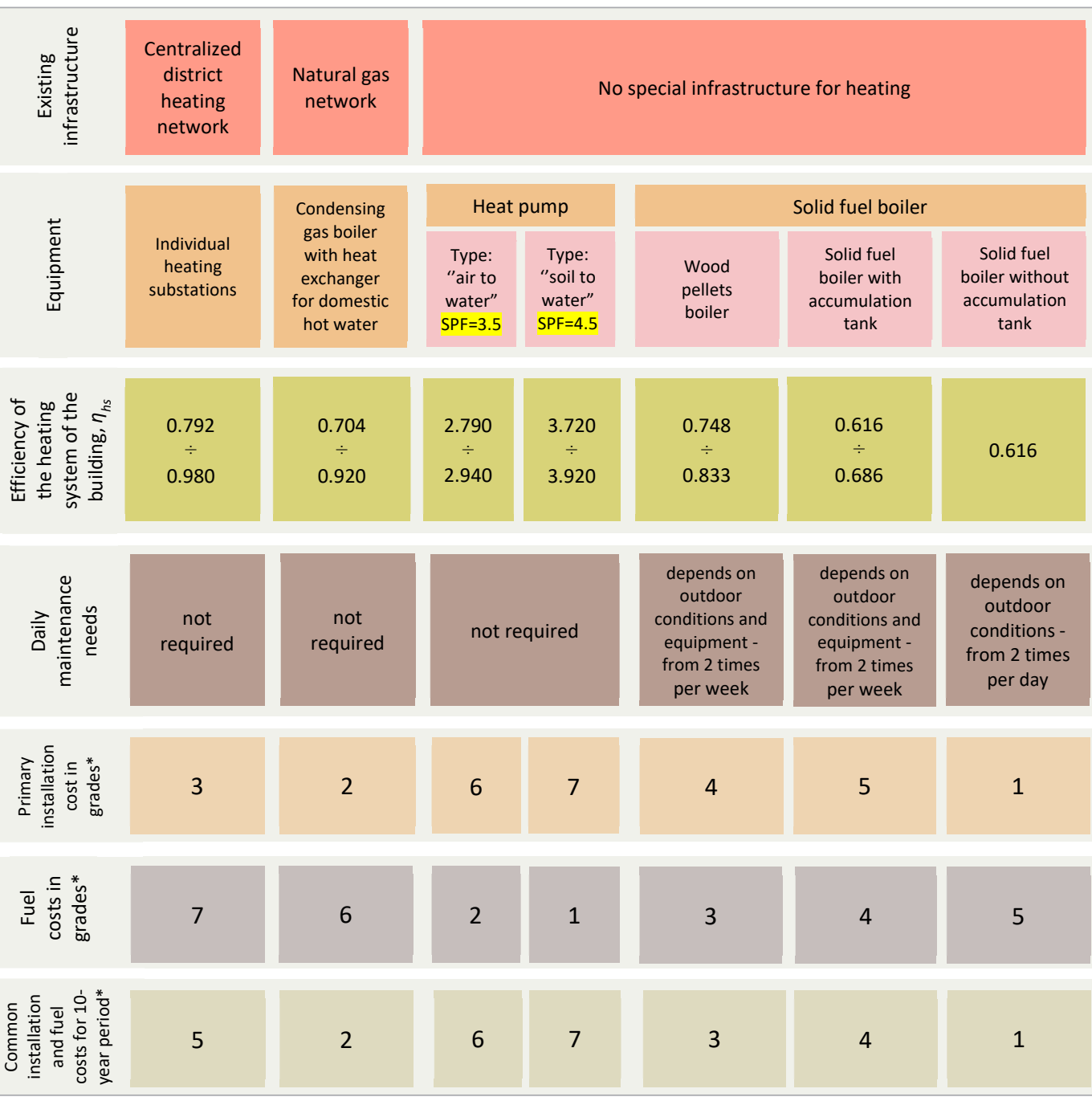

*1-lowest, 7-highest 
The figure shows quick evaluation of possible heating alternatives and gives qualitative and quantitative comparison of different types of heating. The efficiency of the heating system of the building $\left(n_{h s}\right)$ is calculated evaluating possible manual and automatic regulation both of the heating source and heating system. It is noticeable that automatic regulation and additional equipment plays an important role in the whole system evaluation, because automatically regulated system with a solid fuel boiler and accumulation tank $\left(n_{h s}=0.686\right)$ can be near to the condensing gas boiler without automatic regulation $\left(n_{h s}=0.704\right)$. Quantitative data for the grade evaluation of the heating system installation and exploitation costs is taken from Table 8. Grade "1" indicates the lowest cost level and grade " 7 " indicates the most expensive implement.

Analyzing the data presented in Fig. 2 it should be noted that because of the rising economic situation in the country, increasing income and people business ones of the most important criteria for choosing the most suitable heating system is its reliability and efficiency. Operating costs of the heating systems are not so important as it was 10 or 15 years ago. The data presented in this study reflects the current state of installation and operation of heating systems.

It is assumed that the situation will change slightly in the future. Looking at the prospect of 20-30 years, oil and its price will be a major and decisive factor in the global economic development. Changes in oil prices will affect natural gas, energy for transport and other energy sources prices. The data presented in Fig. 2 should be relevant in the future while selecting the heating system for residential buildings.

Due to good infrastructure, Lithuanian consumers usually have many alternatives in choosing a heat source - from district heating to the gas boilers. Many objective and subjective criteria should be taken into account in order to determine the most suitable heat source. The main criteria that should be evaluated are: installation and exploitation costs, daily maintenance needs, additional space for the equipment and the influence of selected heat source to the energy efficiency of the building.

The lowest installation and fuel cost for the 10-year period can be reached by using solid fuel (firewood) boiler without accumulation tank (8566Eur) if daily maintenance of the boiler is acceptable. When the infrastructure of gas supply network is available a condensing gas boiler with heat exchanger for domestic hot water can give minimal maintenance and space saving with $26,6 \%$ increase of total price (10849Eur). Higher primary installation cost (11800Eur) for heat pump (type "soil to water") does not guarantee the lowest total price for the 10-year period.

Since there are many options to combine the heat source for a building, additional analysis could be made to evaluate the cost of heat pump combined with solar panels etc.

Bosh J., Johnson FX., Mertens R., Roubanis N., Loesoenen P., Gikas A., et al. Panorama of Energy: Energy Statistics to Support EU Politics and Solutions. Eurostat; 2008.

Černeckienè, J., Vaičiūnas, J., Valančius, R., Jurelionis A., Zdankus T. Recent Advancements in the Use of On-site Biomass systems in the Build Environment. Current Sustainable/Renewable Energy Reports. 2018; 5(2) 156-162.

Directive 2010/31/EU of the European Parliament and of the Council of 19 May 2010 on the energy performance of buildings. Available at: https://eurlex.europa.eu/legal-content/EN/ALL/?uri=celex\%3A32010L0031 [accessed 10 May 2018].

EHPA 2017. European heat pump market and statistics report 2017. Available at: http://www.ehpa. org/about/news/article/european-heat-pumpmarket-and-statistics-report-2017-is-availablenow/ [accessed 6 May 2018].

ESO 2017. Tyrimas: kiek kainuojanamu siluma? Available at: http://www.eso.lt/lt/ziniasklaida/tyrimas-kiek-kainuoja-namu-siluma.html [accessed 7 May 2018].

European Commission 2011. COM (2011) 112 Final. Commission communication. Roadmap to a competitive low carbon economy in 2050; 2011.

European Commission 2018. Available at: https:// ec.europa.eu/energy/en/topics/energy-efficiency/ buildings [accessed 2 May 2018].

European Commission. Draft Horizon 2020 Work programme 2014-2015 in the area of secure, clean and efficient energy; 2015.

\section{Conclusions}

\section{References}


Galvonaitė A. et al. Lietuvos hidrometeorologijos tarnybos prie Aplinkos ministerijos Klimatologijos skyrius: Vidutinès klimatiniu rodikliu reikšmès Lietuvoje 1981-2010 m. (Climate averages for Lithuania 1981-2010) 2013. Access via internet: http:// www.meteo.lt/documents/20181/103901/Lietuvos_klimatas_09_25.pdf.

Honkapuro S., Koreneff G. Heat pumps and other DER technologies in Finland. IEA DSM Agreement. Task XVII Integration of DSM, DG, RES and storages. Workshop in Sophia Antipolis, France. 2011. Available at: http://www.ieadsm.org/ViewTask.aspx?|D=16\&Task=17\&Sort=0 [accessed 10 May 2018].

LSTA 2011. Silumos vartotojo vadovas. Pirmas priedas. Available at: http://lsta.lt/files/Leidiniai/ SILUMOS_vartotojo_vadovas/Silumos_vadovo_ Priedas\%20koreg.pdf [accessed 8 May 2018].

LSTA 2018. Lietuvos Šilumos tiekejju asociacija. Vidutine šilumos kaina gyventojams (po perskaičiavimu). Available at: http://lsta.lt/lt/pages/apie-silumos-uki/silumos-kainos [accessed 25 April 2018].

Regula 2017. Valstybinè kainu ir energetikos kontrolès komisija. Visuomeniniai tarifai AB "Energijos skirtymo operatorius” nuo 2017 m. sausio 1 d. Avail- able at: https://www.regula.lt/elektra/Puslapiai/tarifai/visuomeniniai-tarifai-ab-ENERGIJOS-SKIRSTYMO-OPERATORIUS-nuo-2017-m--sausio-1-d.aspx [accessed 25 April 2018].

Regula 2018. Valstybinè kainų ir energetikos kontrolès komisija. Gamtinių duju arifai buitiniams vartotojams nuo 2018 m. liepos 1 d. [accessed 25 April 2018].

RSN 156-94. Statybine klimatologija. Vilnius: Renkon; 1994.

STR 2.01.02:2016. Pastatu energetinio naudingumo projektavimas ir sertifikavimas. Available at: https:// www.e-tar.lt/portal/lt/legalAct/2c182f10b6bf1 1e6aae49c0b9525cbbb [accessed 11 May 2018].

Streimikiene D. Residential energy consumption trends, main drivers and policies in Lithuania. Renewable and Sustainable Energy Reviews. 2014; (35) 285-293. https://doi.org/10.1016/j.rser.2014.04.012

Stuart JS., Bale V., Reddy MA. Rosen Geothermal heat pump systems: Status review and comparison with other heating options. Applied Energy. 2013; (101) 341-348. Šilumos tiekimo ir vartojimo taisykles (en. Rules for supply and consumption of thermal energy) Order of Energy minister of Lithuanian Republic. 2010, No. 1-297.

\section{About the Authors}

\section{JURGITA CERNECKIENE}

Lecturer

Kaunas University of Technology, Faculty of Civil Engineering and Architecture

\section{Main research area}

Energy performance in buildings, HVAC systems, renewable energy

\section{Address}

Studentu st. 48, LT-51367 Kaunas, Lithuania Tel.+37061531533 E-mail: jurgita. cerneckiene@ktu.lt

\section{ROKAS VALANCIUS Lecturer Kaunas University of Technology, Faculty of Civil Engineering and Architecture}

\section{Main research} area

Renewable energy, indoor climate, energy performance in buildings

\section{Address}

Studentu st. 48, LT-51367 Kaunas,

Lithuania

Tel. +37068010000

E-mail: rokas. valancius@ktu.lt
LAURA STASIULIENE

Lecturer

Kaunas University of Technology, Faculty of Civil Engineering and Architecture

\section{Main research area}

Indoor air quality, thermal comfort, HVAC systems, energy efficiency, building information modelling (BIM)

\section{Address}

Studentu st. 48, LT-51367 Kaunas, Lithuania E-mail: laura. stasiuliene@ktu.lt

\section{EUGENIJUS PEREDNIS}

Senior research associate

Lithuanian Energy Institute, Laboratory for Renewable Energy and Energy Efficiency

Main research area

Energy efficiency of buildings, usage of solar, wind and biomass energy

\section{Address}

Breslaujos str. 3 , LT-44403 Kaunas, Lithuania E-mail: eugenijus. perednis@lei.lt
JUOZAS VAICIUNAS

Lecturer

Kaunas

University of Technology, Faculty of Civil Engineering and Architecture

Main research area

Waste water energy

Address

Studentu st. 48, LT-51367 Kaunas, Lithuania E-mail: juozas. vaiciunas@ktu.lt 